\title{
Are flood-driven turbidity currents hot spots for priming effect in lakes?
}

\author{
Damien Bouffard $^{1}$ and Marie-Elodie Perga ${ }^{2}$ \\ ${ }^{1}$ Physics of Aquatic Systems Laboratory, Margaretha Kamprad Chair, EPFL-ENAC-IEE-APHYS, \\ 1015 Lausanne, Switzerland \\ ${ }^{2}$ INRA-Université Savoie Mont Blanc, UMR042 CARRTEL, Thonon-les-Bains, France \\ Correspondence to: Marie-Elodie Perga (marie-elodie.perga@thonon.inra.fr)
}

Received: 15 December 2015 - Published in Biogeosciences Discuss.: 18 January 2016

Revised: 20 May 2016 - Accepted: 27 May 2016 - Published: 20 June 2016

\begin{abstract}
In deep stratified lakes, such as Lake Geneva, flood-driven turbidity currents are thought to contribute to the replenishment of deep oxygen by significant transport of river waters saturated with oxygen into the hypolimnion. The overarching aim of this study was to test this longstanding hypothesis directly. It combines direct observational data collected during an extreme flooding event that occurred in May 2015 with dark bioassays designed to evaluate the consequences of river-borne inputs for the hypolimnetic respiration. The exceptional precipitation events of May 2015 caused floods with an annual return time for the Rhône River, the dominant tributary of Lake Geneva, and with 50-year return time for the Dranse River, the second-most important tributary. Sediment-loaded river flows generated turbidity currents plunging into the lake hypolimnion. The observed river intrusions contributed to the redistribution of dissolved oxygen, with no net gain, when occurring in the lowermost hypolimnetic layer. In the uppermost hypolimnion above the last deep-mixing event, the intrusions coincided with a net oxygen deficit. Consistent with field observations, dark bioassays showed that 1 to $50 \%$ substitution of riverine organic matter to deep $(<200 \mathrm{~m})$ hypolimnetic water did not affect microbial respiration, while the addition of 1 to $10 \%$ of riverine water to the uppermost hypolimnetic waters resulted in a respiration over-yielding, i.e. excess respiration of both river-borne and lacustrine organic matter. The results of our study conflict with the hypothesis that flood-driven turbidity currents necessarily increase hypolimnetic oxygen stocks in Lake Geneva. In contrast, results show that flood-driven turbidity currents can be potential hot spots for priming effect in lakes.
\end{abstract}

\section{Introduction}

In thermally stratified lakes, river water inflow occurs under two different modes. Under normal (i.e dry-weather) flow conditions, the river water is injected at the interface between the warm, upper layer (epilimnion) and the cold, lower layer (hypolimnion), forming an interflow in the upper thermocline (Fischer, 1979) or at the surface. Particularly during flood events, high concentrations of suspended sediments in rivers increase the density of inflowing waters and therefore generate turbid density currents following the slope and flowing into the hypolimnion (i.e. hyperpycnal plume). Their dynamics are divided into three distinct stages (Alavian et al., 1992; Cortés et al., 2014; Hogg et al., 2013). First, the river dense water pushes the ambient lake water until the resulting baroclinic pressure created by the local density difference between the river and the lake water balances the force of the momentum inflow. At this stage, the river flow plunges (plunging stage); then the flow continues to run along the lake bed as an underflow (underflow regime). The flow eventually reaches the depth of neutral buoyancy, separates from the lake bottom and intrudes into the lake (intrusion stage).

Lake observations of such river-borne turbidity currents date back to the late 19th century in Lake Geneva (Forel, 1892), and more recent reports indicate that they occur in many perialpine lakes such as Walensee (Lambert et al., 1976), Lake Geneva (Lambert and Giovanoli, 1988), Lake Lucerne (Wüest et al., 1988), Brienzer See (Finger et al., 2006), and Lake Lugano (De Cesare et al., 2006). Marine underflows are also common features (Mulder et al., 2003).

Besides their implications for the physical structure of subaquatic environments (Meiburg and Kneller, 2010), under- 
flows have been considered for their potential biogeochemical consequences for lakes. For instance, in Lake Geneva, the long-standing hypothesis has been that river intrusions could replenish deep oxygen, and this hypothesis was supported by several, albeit indirect, field observations. Fahrni and Rapin (1986) compiled the densities of Lake Geneva hypolimnetic waters and those of the Rhône River over 7 years and suggested that some of the time periods prone to river underflows coincided with partial oxygen replenishment in the deepest layers of the lake's central area (long-term monitoring station SHL2). Meybeck et al. (1991) pointed out relatively frequent and important oxygen and silicate anomalies occurring close to the sediment-water interface at the reference monitoring station SHL2 and invoked river-borne underflows, along with alternative mechanisms (accumulation of turbid, cold water on lake banks after severe storms), as being responsible for these anomalies.

Lake Geneva has been suffering from deep-water hypoxia since its early eutrophication in the late 1950s (Jenny et al., 2014). Based on the hypothesis of oxygen-rich river water intrusions (Meybeck et al., 1991), underflows following episodes of heavy rainfalls are expected to counteract hypoxia by supplying oxygen to the stratified lake hypolimnion (Jenny et al., 2014). Yet, numerous hydroelectric dams have been constructed along the course of the Rhône River, leading to a shift in the seasonal discharge pattern (Loizeau and Dominik, 2000). Consequently, large floods, mostly occurring in summer, were reduced in amplitude and frequency, also leading to a decrease in sediment input by at least a factor of 2 (Loizeau and Dominik, 2000). This summer discharge and bulk plume density reduction impacted the occurrence of underflows along the lake bottom and is thought to aggravate deep-water hypoxia. However, despite their crucial functional implications for hypolimnetic oxygen concentrations, the consequences of turbidity currents, and of their further decrease in occurrence, have actually never been investigated directly.

The condition for the river-borne currents to reach the bottom of the central basin is that the hyperpycnal plume is not diluted by lake water as it advances within a lake (Turner, 1986). Yet, sediment-loaded underflows, as those expected during floods, differ from underflows observed during the regular river regime, whose density is only controlled by temperature. While the latter typically intrudes into the metalimnion, as recently revealed by isotope tracing (Halder et al., 2013), the former undergoes a dynamic density change, generating multiple underflows and therefore increasing the overall dilution (Cortés et al., 2014). In addition, underflows may primarily act on the hypolimnion by pushing deep waters upwards (Wüest et al., 1988), therefore redistributing oxygen within deep layers, rather than contributing to a net oxygen gain, as observed in nearby Lake Lugano (De Cesare et al., 2006).

Besides these positive and null hypotheses, an alternative, metabolic hypothesis is formulated here based on the observed impact of floods on the carbon budgets of some lakes around the world. A common opinion is that the bulk of the organic carbon that enters surface water is refractory and may only contribute little to bacterial metabolism in comparison to autochthonous sources (Moran and Hodson, 1990). However, the composition and hence quality of dissolved organic matter entering lakes depends on the watershed coverage, land use, climate, and hydrology (AlvarezCobelas et al., 2010) and may also be highly variable during the year (Berggren et al., 2009). Increased inputs of fresh organic material during storm waters and spring floods (Agren et al., 2008; Dhillon and Inamdar, 2013; Raymond and Saiers, 2010) have been shown to push lake metabolic balances further into heterotrophy (Klug et al., 2012; Sadro et al., 2011; Tsai et al., 2008), either by decreasing surface primary production through lower water transparency or by stimulating bacterial respiration through the addition of labile, terrestrial organic matter (Johengen et al., 2008; Ojala et al., 2011; Vachon and Giorgio, 2014). Considering the size of Lake Geneva, it is unlikely that floods may affect the whole ecosystem metabolism (Vachon and Giorgio, 2014). Yet, since river-borne intrusions are rich in organic matter, they could locally be hot spots for bacterial respiration that would counteract the net oxygen inputs into the hypolimnion. In this metabolic hypothesis, river-borne intrusions could cause a null or even a negative effect on hypolimnetic oxygen concentrations.

The overarching aim of this paper was, therefore, to study the net oxygen effect of flood-driven river-borne intrusions into Lake Geneva. The study combined direct observational data collected during an extreme flooding event in May 2015 while the lake was already stratified, supported by an experimental test designed to evaluate the consequences of river water inputs for the hypolimnetic respiration.

\section{Materials and methods}

\subsection{Field survey}

Lake Geneva is the largest lake of western Europe in terms of volume $\left(89 \mathrm{~km}^{3}\right)$, and one of the deepest $(309 \mathrm{~m})$. In total, $84 \%$ of the water input originate from the two main rivers, the Rhône $(75 \%)$ and the Dranse $(9 \%)$, both flowing into the eastern basin. The river discharge and water quality are continuously monitored by the FOEN (Federal Office for the Environment, Switzerland for the Rhône), the DREAL (Direction Régionale de l'Environnement, de l'Aménagement et du Logement; for discharge of the Dranse River, see http://www.hydro.eaufrance.fr/stations/V0334010), and the Observatory of Alpine Lakes (for the water quality of the Dranse, see http://www6.inra.fr/soere-ola). The discharge (hourly record) and water quality (2-week integrated sample) of the Rhône River are monitored at Porte-du-Scex FOEN station, $6 \mathrm{~km}$ upstream of the Rhône inflow. The discharge of 
the Dranse is recorded at the Reyvroz hydrological station, $20 \mathrm{~km}$ upstream of the Dranse inlet to Lake Geneva, while water quality surveys are performed close to the river delta.

The Rhône River hydrological regime was originally of a typical glacier type but the exploitation of the river flow for hydroelectrical production has substantially smoothed the seasonal variability of water discharge over the latest 40 years. Summer discharges are currently only twice those observed in winter (Loizeau and Dominik, 2000). The average annual discharge at Porte-du-Scex in May over 1935-2013 was $208 \mathrm{~m}^{3} \mathrm{~s}^{-1}$. The Dranse, which is the second-most important tributary of Lake Geneva, has a typical nival flow regime (Meybeck et al., 1991), with a maximum discharge in May (average discharge in May over 1906-2003: $39 \mathrm{~m}^{3} \mathrm{~s}^{-1}$ ).

The consequences of the heavy rain of 1-5 May 2015 on physico-chemical lake properties were investigated through a specific lake survey. In total, 24 sites were sampled within 1 day (7 May 2015) with a multi-parameter profiler (Sea\&Sun Technology, CTD-90 multi-parameter probe), which includes measurements of depth, temperature $(T)$, conductivity, turbidity $(\mathrm{Tu})$, and dissolved-oxygen concentration $\left(\mathrm{O}_{2}\right)$. The $\mathrm{O}_{2}$ oxyguard (Clark type) is regularly calibrated with a long-term stability optode (Anderaa 4330F), but, in the present study, no drift in the $\mathrm{O}_{2}$ measurements was expected during a single-day survey.

The 24 sampling sites cover an area of $\sim 200 \mathrm{~km}^{2}$ over the eastern basin. The sampling design was specifically intended to sample the influence of the two main rivers and to investigate the local influence of deep intrusions on $\mathrm{O}_{2}$ concentrations. For this reason, all sites were chosen with a local depth largely exceeding $100 \mathrm{~m}$. Particular care was taken to encompass the main active sublacustrine canyons of the Rhône and of the Dranse, as well as their surroundings, and therefore to optimize the chance to probe intrusion plumes. The high-resolution CTD survey provided spatial information of $\mathrm{O}_{2}$, Tu, and $\mathrm{T}$. Maps of hypolimnetic properties were constructed with kriging interpolation method.

The net effect of river intrusion on the dissolved-oxygen concentration was quantified by comparing the $\mathrm{O}_{2}$ profile within the intrusion layer to a theoretically observed linearly decreasing $\mathrm{O}_{2}$ profile within this layer as typically observed in intrusion-free (undisturbed) CTD profiles.

\subsection{Oxygen consumption experiment}

In order to test whether inputs of riverine organic carbon within the lake hypolimnion could drive significant oxygen consumption via microbial respiration, an incubation experiment was conducted in October 2015. On 19 October, 15 L of Lake Geneva hypolimnetic water were collected with a VanDorn bottle from 100 and $200 \mathrm{~m}$ depths at SHL2, as well as $20 \mathrm{~L}$ of water from the Dranse, at less than $1 \mathrm{~km}$ from its entrance into Lake Geneva. One litre of lake and river water was kept in a glass bottle for further analyses of carbon (C), nitrogen $(\mathrm{N})$, and phosphorus $(\mathrm{P})$ contents. Concentrations
Table 1. Design of the incubation experiment.

\begin{tabular}{lcr|r}
\hline & \multicolumn{2}{c}{ Percent composition } \\
\cline { 2 - 4 } & \multicolumn{2}{c}{ Lake water } & Dranse water \\
\cline { 2 - 4 } $\begin{array}{l}\text { Sample } \\
\text { designation }\end{array}$ & $\begin{array}{r}\text { 200 m depth } \\
\text { lake water }\end{array}$ & $\begin{array}{r}100 \mathrm{~m} \text { depth } \\
\text { lake water }\end{array}$ & \\
\hline L200-100\% & $100 \%$ & & \\
L200-99\% & $99 \%$ & & $1 \%$ \\
L200-90\% & $90 \%$ & & $10 \%$ \\
L200-50\% & $50 \%$ & & $50 \%$ \\
L100-100\% & & & $100 \%$ \\
L100-99\% & & $90 \%$ & $1 \% \%$ \\
L100-90\% & & & $100 \%$ \\
D-100\% & & & \\
\hline
\end{tabular}

in total and dissolved organic C (TOC, DOC) were measured with and without filtration on Whatman GF/F filters $(0.7 \mu \mathrm{m}$ nominal pore size) on a TIC/TOC analyser (OI Analytical). Nutrients were analysed by standard colorimetric methods (Association Française de Normalisation, 1990).

Pure lake and riverine waters, and mixed waters in which different percentages of lake water were substituted by riverine waters, were incubated in $280 \mathrm{~mL}$ hermetically closed glass bottles equipped with SP-PSt3 planar oxygen-sensitive spots (PreSens), according to the experimental design presented in Table 1. The tested range of dilution of riverine waters in the lake hypolimnion was designed based on bulk estimated values of river mixing in Lake Geneva (see Supplement Sect. S1). Triplicates of each sample were incubated in a temperature-controlled dark chamber at $10^{\circ} \mathrm{C}$ (a realistic temperature for river and hypolimnetic conditions during the flood). Changes in $\mathrm{O}_{2}$ over time were measured using a PreSens Fibox 3 equipped with a fibre-optic oxygen transmitter. Initial $\mathrm{O}_{2}$ concentrations were measured $1 \mathrm{~h}$ after the start of the incubation once water temperature had stabilized at $10^{\circ} \mathrm{C}$. Thereafter, $\mathrm{O}_{2}$, and corresponding oxygen consumption, was measured once or twice per day for 4 days. Calibration of the Pre-Sens (two-point calibration at 0 $100 \%$ oxygen saturation) was tested again at the end of the experiment $(<1$ week) and showed no drift over the whole duration of the bioassays. Results were analysed by analysis of covariance (ANCOVA) using $\mathrm{O}_{2}$ consumption as the response variable, treatment as the factor, and time as covariate, including interactions. Further comparisons between treatments or specific dates were performed using Student's $t$ test or Kruskal-Wallis tests in cases of heterogeneous variances. 

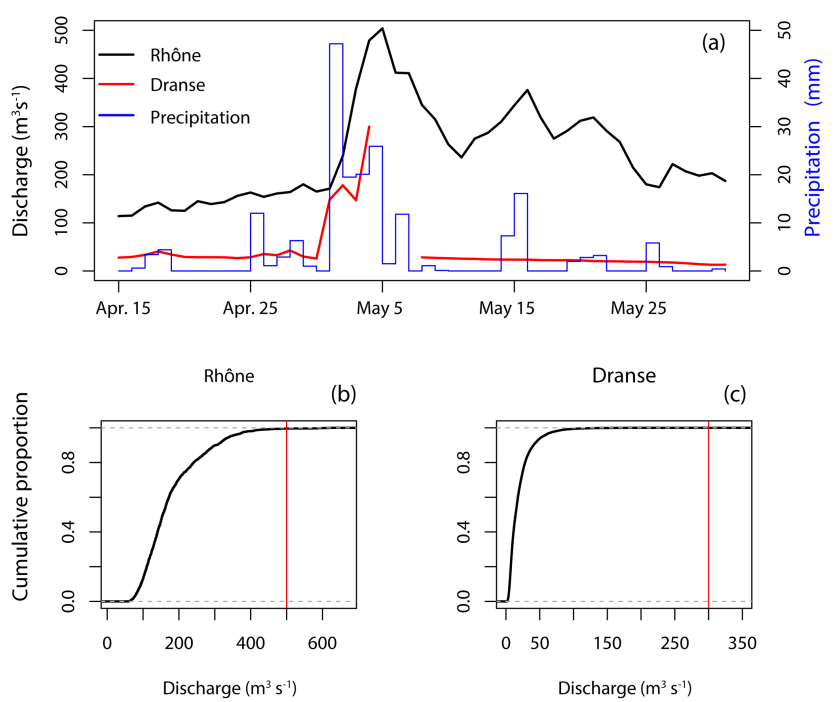

Figure 1. Hydrological characteristics of the flooding event of May 2015. (a) Daily precipitation and discharges of the two dominant tributaries of Lake Geneva, the Rhône and the Dranse rivers, over the months preceding and following the flood. The break in the discharge record of the Dranse corresponds to the date at which the station collapsed. Cumulative distribution of the Rhône discharges in 1976-2009 (b) and Dranse discharges 1957-2014 (c). Red lines indicate the maximum discharges of the May 2015 event.

\section{Results}

\subsection{Field survey}

For the 2015 spring flood events, heavy rainfalls over the Lake Geneva watershed lasted from 1 to 4 May (total rainfall $>100 \mathrm{~mm}$ over these 4 days). For comparison, this is a record amount for the city of Bex (Switzerland), located $20 \mathrm{~km}$ upstream of Lake Geneva along the Rhône River, and was last observed in December 1916. The discharge of the Rhône increased from $\sim 140 \mathrm{~m}^{3} \mathrm{~s}^{-1}$ at the end of April up to a maximum of $504 \mathrm{~m}^{3} \mathrm{~s}^{-1}$ on 5 May (Fig. 1a). This discharge reached the 98 th percentile of the cumulative distribution of the Rhône discharges over 1976-2009 and corresponded to an annual return time of the Rhône floods at the entrance of Lake Geneva (Fig. 1b). The Rhône water temperature was $8^{\circ} \mathrm{C}$ and $\mathrm{O}_{2}$ concentrations were $11 \mathrm{mg} \mathrm{O}_{2} \mathrm{~L}^{-1}$ (data source: FOEN, Switzerland). On the sampling date (7 May), the Rhône discharges remained elevated with a daily average of $\sim 400 \mathrm{~m}^{3} \mathrm{~s}^{-1}$.

The heavy rainfalls of early May 2015 increased the flow of the Dranse, which was already at its seasonal maximum; together, the rainfalls and high flow generated a flood of exceptional amplitude. Between 30 April and 4 May, the discharge increased from 26 to $300 \mathrm{~m}^{3} \mathrm{~s}^{-1}$, right before the monitoring station collapsed (Fig. 1a). This was a new record, exceeding the previous historical maximum discharge ever recorded at the Dranse hydrometric station

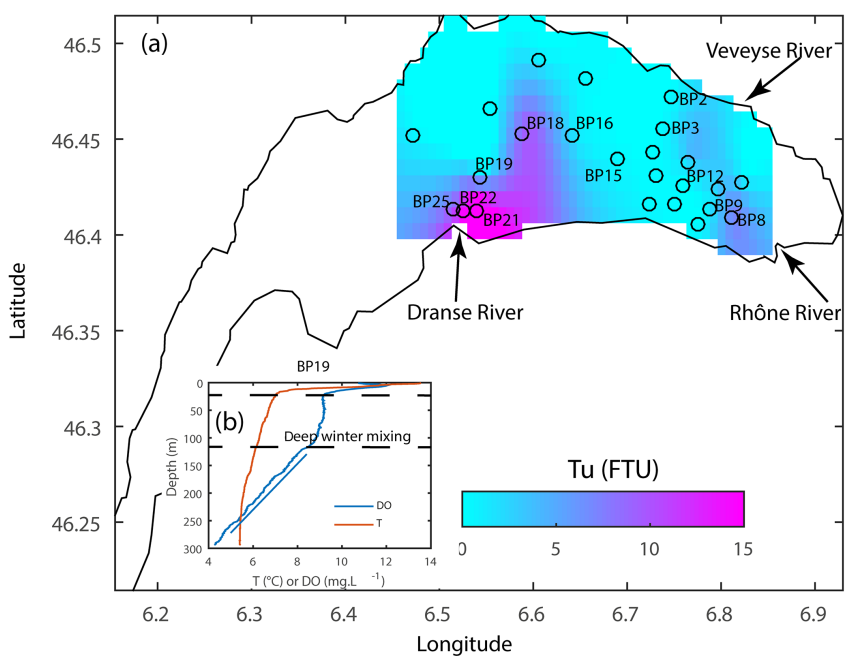

Figure 2. Spatial distribution of maximum hypolimnetic turbidity (40-300 m depth) as a tracer for flooding river intrusions. Identified stations are those for which profiles were provided in Fig. $3 \mathrm{~b}$. The inserted figure shows typical temperature and $\mathrm{O}_{2}$ profiles for an undisturbed station. Note the linear decrease in $\mathrm{O}_{2}$ with depth in the lower hypolimnion (below the deep winter maximum). GPS location of the CTD profiles is indicated in Table S5 in the Supplement.

$\left(229 \mathrm{~m}^{3} \mathrm{~s}^{-1}\right.$ on 22 September 1968). The estimated return time of the 2015 flood event for the Dranse was 50 years (Fig. 1c). The flooding waters were highly turbid with a concentration of suspended matter reaching $>2000 \mathrm{mg} \mathrm{L}^{-1}$ (averaged concentration of $18 \mathrm{mg} \mathrm{L}^{-1}$ in 2014; data from the Observatory of Alpine Lakes, France). The suspended organic-matter concentration was $195 \mathrm{mg} \mathrm{L}^{-1}$ (annual average of $5 \mathrm{mg} \mathrm{L}^{-1}$ in 2014). DOC was twice the average annual concentration (2.3 vs $1.2 \mathrm{mgCL}^{-1}$ ). Dissolved nutrient concentrations were moderate $\left(\mathrm{PO}_{4}^{3-}=10 \mu \mathrm{g} \mathrm{P} \mathrm{L}{ }^{-1}\right.$; $\left.\mathrm{NO}_{3}^{-}=480 \mu \mathrm{g} \mathrm{NL}^{-1}\right)$. Although not regularly monitored, the highly torrential flow of the Dranse suggests saturated oxygen concentrations.

The flood inflows are highly turbid compared to Lake Geneva waters ( $<5$ FTU), and turbidity was thereafter used as a tracer for intrusive waters within the lake. CTD profiles for all surveyed stations are provided as a Supplement (Fig. S2). Of the 24 sites, more than $50 \%$ had hypolimnetic turbidity peaks attributed to river intrusions (Fig. 2). The use of turbidity as a proxy for river-borne waters was also validated by temperature profiles showing a consistent increase in temperature in the turbid layers and thereby indicating that, locally, the density of the water was significantly affected by suspended matter and no longer a function of temperature and salinity only (see Fig. S2). This trend is clearly noticeable in BP18, located within the far Dranse underflow (Fig. 3a and b). The turbidity signal from the Rhône was restricted to the few stations located less than $2 \mathrm{~km}$ downstream (BP8 and 9), while the turbidity current from the Dranse pen- 
etrated much further into the lake, even reaching the reference monitoring station (SHL2 = BP18), $6 \mathrm{~km}$ downstream. The two northernmost stations BP2 and 3 were within the small but noticeable underflow of the Veveyse River (Fig. 2). Except for the stations closest to the Rhône (BP8) and Dranse (BP21, 22 and 25), the underflow was split between two different hypolimnetic layers: a very turbid underflow within the lower hypolimnion (below $110 \mathrm{~m}, \mathrm{BP} 5,7,9$, and 13 for the Rhône underflow, BP16 and 18 for the Dranse River), and a less turbid underflow between 50 and $110 \mathrm{~m}$ depths (BP2 and 29).

Undisturbed profiles typically indicated a similar trend in $\mathrm{O}_{2}$ slope $\left(\Delta \mathrm{O}_{2} / \Delta\right.$ depth $=-0.022 \mathrm{mg} \mathrm{L}^{-1} \mathrm{~m}^{-1}$, SD $0.006 \mathrm{mg} \mathrm{L}^{-1} \mathrm{~m}^{-1}$, based on nine profiles, BP13, 4,6 , $11,12,14,19$, and 28; Fig. S1) in the lower hypolimnion defined as the region below the winter deep-mixing maximum $(110 \mathrm{~m})$ and the layer of influence of the bottom $(20 \mathrm{~m}$ above the sediment interface). The winter deep-mixing maximum at depth $110 \mathrm{~m}$ was also confirmed by a CTD profile carried out 1 week earlier by the Observatory of Alpine Lakes, France (not shown). Although more contrasted, the upper hypolimnion, i.e. between the thermocline depth and the winter deep-mixing depth (Fig. 2b), was characterized by a less steep $\mathrm{O}_{2}$ slope (e.g. the upper hypolimnion had mixed 3 months earlier).

The net effect of the intrusion on $\mathrm{O}_{2}$ was first assessed by comparing intrusion-affected and the nearest intrusion-free CTD profiles (Fig. 3). Surprisingly, at no sampling site did the turbidity peak match with a local maximum in $\mathrm{O}_{2}$ that could compare to the lens anomalies reported by Meybeck et al. (1991). Instead, the depths of the turbidity peak coincided with a disruption of the background decreasing trend in $\mathrm{O}_{2}$ as a function of depth, clearly noticeable for instance in the comparison of the $\mathrm{O}_{2}$ profiles at BP18 (affected by the Dranse) and BP16 (not affected, Fig. 3a and b). Such a reduction of $\mathrm{O}_{2}$ vertical gradients as recorded at $\mathrm{BP} 5,8,9$, and 18 suggests the formation of a mixed layer due to the increased momentum within the underflow. Depth-averaged $\mathrm{O}_{2}$ in the interval 30 to $270 \mathrm{~m}$ at BP16 and BP18 were identical (7.0 $\mathrm{mg} \mathrm{O}_{2} \mathrm{~L}^{-1}$ ) and, thereby, supported the hypothesis that the studied intrusion and related extreme flood event had no net effect on the $\mathrm{O}_{2}$ concentration but, rather, efficiently mixed turbid-affected hypolimnetic layers. Although the trend was not as clear as in the middle of the lake, similar conclusions arose from the comparison of CTD profiles carried out near the Rhône at BP8 and BP12 (Fig. 3b and c). More information on the Rhône intrusion is provided as Supplement data (Fig. S3).

At stations BP2, 3, 21, 22, 25, and 29, turbid layers above $110 \mathrm{~m}$ depths even coincided with a decrease in $\mathrm{O}_{2}$ concentration. The drop in $\mathrm{O}_{2}$ at BP2 in the turbid layer between 58 and $86 \mathrm{~m}$ is a stunning example, with a decrease in $\mathrm{O}_{2}$ of $\sim 0.3 \mathrm{mg} \mathrm{L}^{-1}$. $\mathrm{O}_{2}$ concentration decline within turbid layers was also observed near the Dranse at BP21, 22, and 25 (Fig. 4). Although all three stations were affected by the
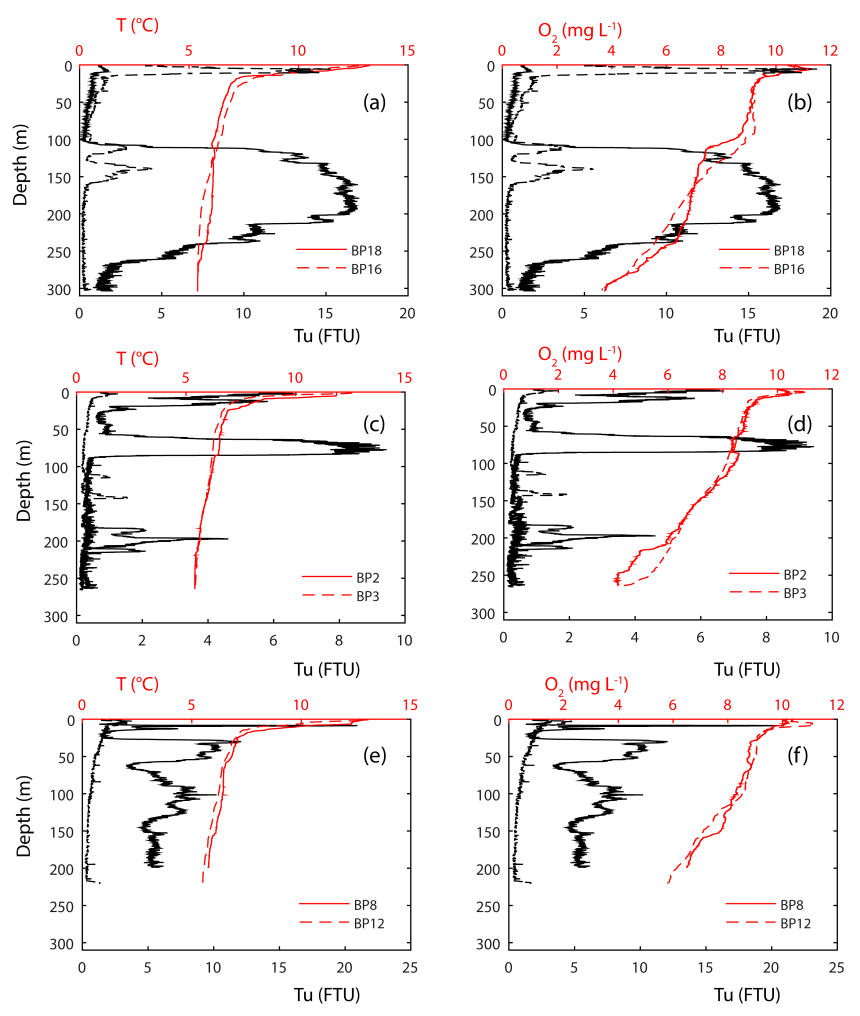

Figure 3. Comparison of temperature, turbidity, and $\mathrm{O}_{2}$ depth profiles for nearby stations, one being undisturbed (dotted lines), and the other highly disturbed (continuous lines) by the turbidity current of the Dranse (a, b), the Veveyse (c, d), and the Rhône rivers (d, e).

Dranse underflow, turbid intrusion was observed at different depths. While $\mathrm{O}_{2}$ of the three stations was highly comparable at depths unaffected by the turbid flow $(15-50 \mathrm{~m})$, their $\mathrm{O}_{2}$ profiles diverged at depths affected by the turbidity current. Below $50 \mathrm{~m}, \mathrm{O}_{2}$ concentration at $\mathrm{BP} 21$ dropped as the turbidity increased, while $\mathrm{O}_{2}$ concentration at BP22 and BP25 remained higher and similar between 50 and $70 \mathrm{~m}$. Below $70 \mathrm{~m}, \mathrm{O}_{2}$ concentration at $\mathrm{BP} 22$ dropped as turbidity increased, and lastly, the turbidity intrusion at $90 \mathrm{~m}$ depth in BP 25 coincided with the collapse of the three $\mathrm{O}_{2}$ profiles (e.g. $\mathrm{O}_{2}$ drop at $\mathrm{BP} 25$ ). Surprisingly, below $110 \mathrm{~m}, \mathrm{O}_{2}$ profiles remained similar at the three stations independently of turbidity values.

The difference in depth-averaged $\mathrm{O}_{2}$ between the measured profile and associated linear fit through the turbid layer provided a first-order parameterization of the net $\mathrm{O}_{2}$ effect of the intrusion. The spatial heterogeneity in large systems prevented the definition of a single reference profile valid for the entire lake. Furthermore, the change in $\mathrm{O}_{2}$ slope at the winter deep-mixing maximum $(110 \mathrm{~m})$ precluded the use of this linear fitting method for any intrusion encompassing this layer (i.e. BP 21, 22, and 25) although oxygen vertical profiles clearly showed evidence for oxygen depletion within the turbid layer (see above). We therefore restricted this analysis 

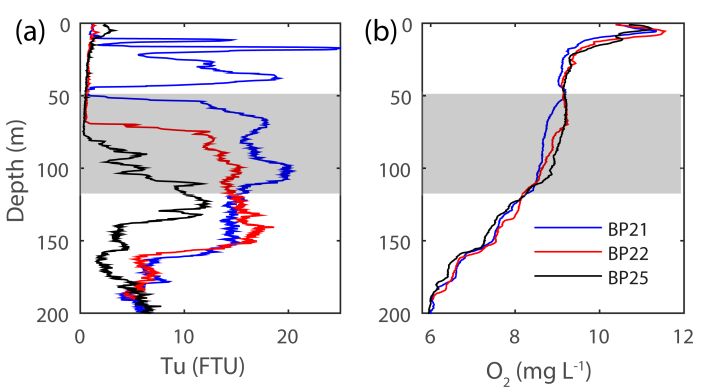

Figure 4. Comparison of turbidity (a) and $\mathrm{O}_{2}$ (b) depth profiles for the three stations close to the Dranse River mouth. The shaded area corresponds to the upper hypolimnion, i.e. water layers that have been mixed during the preceding winter.

to intrusions located in the upper part of the hypolimnion (between the thermocline and the winter deep-mixing maximum) or intrusions located below this winter deep-mixing maximum. Relative changes in $\mathrm{O}_{2}$ in the turbid layers flowing within the lowest hypolimnion $(>110 \mathrm{~m}$ depth) were not significant $\left(-0.07 \mathrm{mg} \mathrm{L}^{-1}\right.$, SD $0.05 \mathrm{mg} \mathrm{L}^{-1}, t=-2.50$, $\mathrm{d} f=4, p$ value $=0.066$; Fig. 6 ). Net oxygen effects associated with turbid layers flowing within the upper hypolimnion were more variable $\left(-0.19 \mathrm{mg} \mathrm{L}^{-1}\right.$, SD $\left.0.16 \mathrm{mg} \mathrm{L}^{-1}\right)$, but they were, on average, significantly negative $(t=-3.68$, $\mathrm{d} f=7, p$ value $=0.007$ ), attesting to an actual oxygen debt at these shallower depths.

\subsection{Oxygen consumption experiment}

The experiment was designed a posteriori in order to explain observed differences in the oxygen net effect of the Dranse intrusion between the upper and the lower hypolimnion (above and below $110 \mathrm{~m}$ depth). In October 2015, DOC concentrations in the lake hypolimnion and in the river were very similar $\left(0.80 \mathrm{mgC} \mathrm{L}^{-1}\right.$ at $100 \mathrm{~m}$ depths, $0.70 \mathrm{mgC} \mathrm{L}^{-1}$ at $200 \mathrm{~m}$ depths, and $0.75 \mathrm{mgCL}^{-1}$ in the Dranse waters). Particulate organic carbon concentrations were low $\left(<0.10 \mathrm{mgC} \mathrm{L}^{-1}\right)$. DOC in the Dranse waters during the experiment were about 3 times lower than those observed during the flood, but, more importantly, DOC concentrations were highly comparable between dilution conditions. As a result, differences in $\mathrm{O}_{2}$ consumption between treatments cannot be driven by initial differences in carbon contents. Standardizing consumed $\mathrm{O}_{2}$ by the amount of initial organic carbon was not necessary.

Dissolved nutrient concentrations were very low in the Dranse at the time of collection. Orthophosphate concentrations were half those recorded during the flood $\left(5 \mu \mathrm{g} \mathrm{PL}^{-1}\right)$, while nitrate concentrations were more similar $(580 \mu \mathrm{g}$ $\mathrm{NL}^{-1}$ ). Orthophosphate concentrations at 100 and $200 \mathrm{~m}$ depth were very comparable to those recorded during the flood (13 and $29 \mu \mathrm{g} \mathrm{PL}^{-1}$, respectively, at both dates), while nitrate concentrations were slightly lower $(620$ and $560 \mu \mathrm{g}$

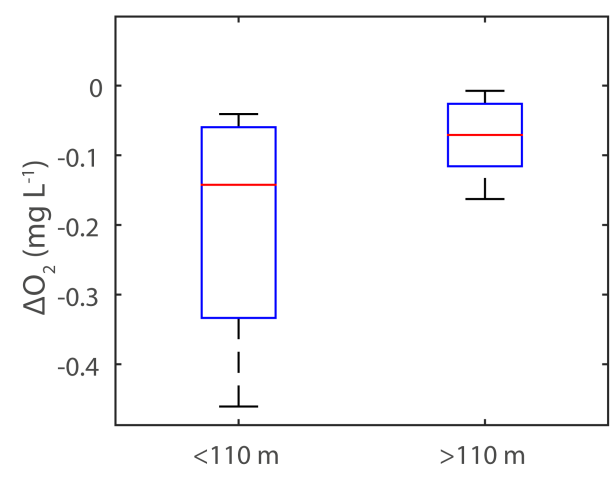

Figure 5. Net effect of the turbidity layer on $\mathrm{O}_{2}$ concentrations calculated for intrusion above $(n=8)$ and below $(n=13)$ the deep winter maximum $(110 \mathrm{~m})$.

$\mathrm{NL}^{-1}$ in October, compared to 670 and $630 \mu \mathrm{g} \mathrm{N} \mathrm{L}-1$ in May 2015).

Initial $\mathrm{O}_{2}$ concentrations were not different between incubation treatments and ranged between 8 and $10 \mathrm{mg} \mathrm{O}_{2} \mathrm{~L}^{-1}$. Beyond 86 or $92 \mathrm{~h}$ of incubations, some treatments (D100\%, L200-100\%, L200-99\%) presented a second phase of increased oxygen consumption that indicated the start of nitrification processes, i.e. oxygen consumption independent of aerobic mineralization. In order to avoid any potential bias due to nitrification, final oxygen consumption values are considered at $86 \mathrm{~h}$ of incubation. $\mathrm{O}_{2}$ consumption after $86 \mathrm{~h}$ was significantly different between treatments (ANCOVA $\left.\mathrm{F}_{7,64}=27, p<2.10^{-16}\right)$ and time $\left(\mathrm{F}_{2,64}=21, p=9.10^{-10}\right)$, with a high consumption rate within the first $20 \mathrm{~h}$ and a relative stabilization thereafter (Fig. 6a, b).

$\mathrm{O}_{2}$ consumption was the highest for the Dranse water, reaching $2.6 \mathrm{mg} \mathrm{O}_{2} \mathrm{~L}^{-1}$ after $86 \mathrm{~h}$, while final values of $\mathrm{O}_{2}$ consumption were significantly lower for the lake waters. Within lacustrine waters, $\mathrm{O}_{2}$ consumption was higher at $200 \mathrm{~m}$ than $100 \mathrm{~m}$ depths $\left(1.0\right.$ and $0.7 \mathrm{mg} \mathrm{O}_{2} \mathrm{~L}^{-1}$, respectively; Kruskal-Wallis $\left.\chi^{2}=4.0, p=0.04\right)$.

The dilution of Lake Geneva water at $200 \mathrm{~m}$ depth by riverine water (L200-100\%, L200-99\%, L200-90\%, and L200-50\%) did not significantly affect the dynamics of $\mathrm{O}_{2}$ consumption over time (ANCOVA, $\mathrm{F}_{\text {treatment } 3,84}=2.0$, $p=0.10$, Fig. $6 \mathrm{a}$ and c). $\mathrm{O}_{2}$ consumption between treatments was therefore not significantly different after $15 \mathrm{~h}$ or beyond of incubation of $200 \mathrm{~m}$ deep water. Observed consumption values were similar to those expected from a linear mixing model. For the 50/50 treatment, consumption was even significantly lower than that expected. In contrast, $\mathrm{O}_{2}$ consumption in lake water collected at $100 \mathrm{~m}$ depths was higher for a treatment with $1-10 \%$ of riverine water added, as compared to the non-diluted samples (ANCOVA, F treatment 2, $66=96$, $p<2.10^{-16}$ ). From $15 \mathrm{~h}$ of incubation and beyond, $\mathrm{O}_{2}$ consumption in samples incubated with $1-10 \%$ of riverine water was significantly (25-150\%) higher than for undiluted samples, although initial carbon content was similar between all 

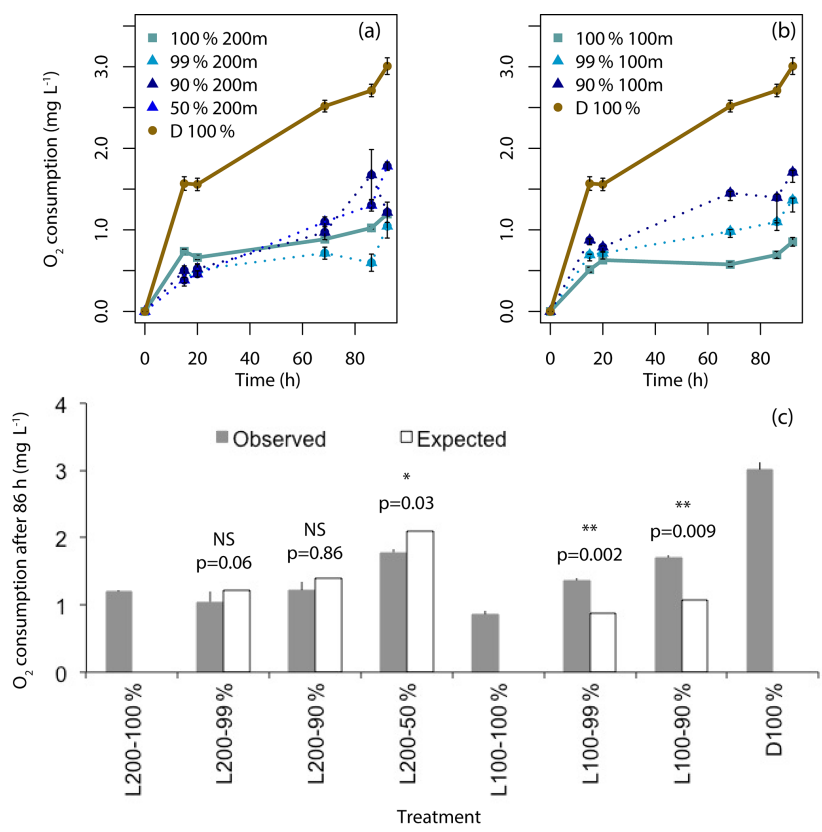

Figure 6. $\mathrm{O}_{2}$ consumption in the bioassays. (a) Bioassays conducted for the lake water collected in the lowermost hypolimnion at $200 \mathrm{~m}$ depth $(100 \% 200 \mathrm{~m})$ and with 1,10 , and $50 \%$ substitution with Dranse water (99\% $200 \mathrm{~m}, 90 \% 200 \mathrm{~m}$, and $50 \% 200 \mathrm{~m}$ ) and compared for Dranse water only (D $100 \%$ ). (b) Bioassays conducted for the lake water collected in the uppermost hypolimnion at $100 \mathrm{~m}$ depth $(100 \% 100 \mathrm{~m})$, with 1 and $10 \%$ substitution with Dranse water $(99 \% 100 \mathrm{~m}, 90 \% 100 \mathrm{~m})$ and compared for the Dranse water (D 100\%). (c) Expected (based on a linear mixing model) and observed (average $\pm \mathrm{SD}$ on triplicates) $\mathrm{O}_{2}$ consumption values after $86 \mathrm{~h}$ incubation of mixed lake and river-borne waters. Specified $p$ values correspond to the outputs of the Student's tests comparing observed and theoretical, expected consumptions.

treatments (Fig. 6b). Observed consumption values after $86 \mathrm{~h}$ exceeded by $60 \%$ those expected from a linear mixing model in both treatments (Fig. 6c).

\section{Discussion}

\subsection{River intrusions during the flooding event}

Considering the extreme intensity of the observed rain event and subsequent river discharges, we expected the floodinduced turbidity current to be heavy enough to trigger an underflow along the lake bed and therefore reach the deepest layers of the water column. However, no clear signatures of a bottom-following underflow could be observed for this specific event. We estimated the sediment load in the Rhône River during the flood event by fitting the relationship between river discharge, $\mathrm{Q}$, and sediment load, $\mathrm{C}$, with a power law $C=a Q^{b}$, as suggested in Loizeau and Dominik (2000) and Mulder et al. (2003). Our best fit for the 50 years of measurements resulted in $a=5.7 \times 10^{-4}$ and $b=2.36$ (see
Fig. S4), which is in good agreement with previously estimated relationships (Loizeau and Dominik, 2000). Based on this relationship, the resulting estimated sediment load at the flood paroxysmal phase reached $1.4 \mathrm{~kg} \mathrm{~m}^{-3}$ (or $\mathrm{g} \mathrm{L}^{-1}$ ). Assuming that the sediment load was predominantly made of quartz $\left(\rho_{\text {sed }}=2700 \mathrm{~kg} \mathrm{~m}^{-3}\right)$, the density of the Rhône River was estimated as $\rho_{\mathrm{R}, \text { tot }}=\rho_{w}(S, T)+\left(1-\rho_{\text {sed }} / \rho_{w}(S, T)\right)$ $a Q^{b}=1000.7 \mathrm{~kg} \mathrm{~m}^{-3}$, where $\rho_{w}(S, T)$ is the density of the water depending on the temperature and salinity (Chen and Millero, 1986). This value was slightly lower than the density of the lake water at the deepest location $\left(1001.4 \mathrm{~kg} \mathrm{~m}^{-3}\right)$ and did not account for the later entrainment of lake water into the intrusion. Similar estimates for the Dranse provided $\rho_{\mathrm{R}, \mathrm{tot}}=1001.2 \mathrm{~kg} \mathrm{~m}^{-3}$ assuming the same river temperature than for the Rhône. Similar first-order calculation suggests that the lower part of the intrusion stopped at $\sim 160 \mathrm{~m}$ for Rhône water and at $\sim 250 \mathrm{~m}$ for Dranse water, which is in very good agreement with the observations. Our results therefore confirm that a Rhône discharge with annual return time is actually plunging. However, the underflow may find its equilibrium density in the hypolimnion and further evolve as an intrusion rather than a true hyperpycnal current, for which much higher discharges are required. Recent observations of a thick turbidite in Lake Geneva sedimentological patterns were, for instance, interpreted as the result of a major underflow and resulting landslides in October 2000 (Corella et al., 2014) with an extremely strong Rhône discharge of nearly $1400 \mathrm{~m}^{3} \mathrm{~s}^{-1}$ (return time 300 years) and a sediment load of $>9 \mathrm{~kg} \mathrm{~m}^{-3}$. Hence, although Lambert and Giovanoli (1988) recorded 11 underflows associated with elevated or rapidly changing discharge in the Rhône canyon, $\sim 2.5 \mathrm{~km}$ away from the river mouth over a short 3-month period in summer 1985, we could not time-correlate any of these underflows to any of the $\mathrm{O}_{2}$ anomalies studied by Meybeck et al. (1991) (see Bouffard and Perga, 2016) in the same year in the deepest $50 \mathrm{~m}$ of the lake $(269-309 \mathrm{~m})$. This suggests that none of these underflows were ultimately strong enough to travel far into the lake. Alternatively the previously postulated relationship between $\mathrm{O}_{2}$ anomalies and Rhône underflows as suggested by Meybeck et al. (1991) is questionable as our observation shows that a 1-year return time discharge rate triggers a plunging underflow that will quickly degenerate into a deep intrusion. Underflows evolving up to the centre of the lake require strong discharge with return times longer than 1 year and are therefore infrequent. Due to its closer location to the lake centre, the Dranse is more likely to affect the lake centre (BP18, SHL2) with interflow (present study) or underflow (Meybeck et al., 1991). Note also that Meybeck et al. (1991) remained inconclusive regarding the exact cause of the observed deep underflow. Besides river inflow, the authors also suggest the influence of winter cooling and a subsequent along-slope oxygen-rich density current as another plausible mechanism. Apparent discrepancies between observed patterns and the hypotheses of Meybeck et al. (1991) are further discussed in Bouffard and Perga (2016). 


\subsection{Consequences of river intrusions on hypolimnetic oxygen concentrations}

Overall, the dataset presented herein disproved the hypothesis of a net oxygen gain due the river intrusions into Lake Geneva during this important flooding event.

When comparing our results to those that supported this original hypothesis, it seems that the net effect of river intrusions on hypolimnetic oxygen concentrations of Lake Geneva varies depending on the properties of the intrusion flow. In May 2015, neither the Dranse nor the Rhône generated an underflow plunging to the lake bottom and we cannot exclude the possibility that such hyperpycnal flows could indeed contribute to deep-water oxygen replenishment. Instead, we observed two types of intrusions, i.e. into the upper hypolimnion that had been previously mixed during the preceding winter and into the lower hypolimnion. Intrusions into the lower hypolimnion acted essentially through their mixing momentum and partly redistributed oxygen within the mixed layers, however without any net benefit. Intrusions above $110 \mathrm{~m}$ depths consistently generated local oxygen depletion. Before the flood, $\mathrm{O}_{2}$ concentrations in the upper hypolimnion were higher than in the lower hypolimnion $\left(9.5 \mathrm{mg} \mathrm{O}_{2} \mathrm{~L}^{-1}\right.$ and $<7 \mathrm{mg} \mathrm{O}_{2} \mathrm{~L}^{-1}$, respectively) because the winter mixing did not reach deeper than $110 \mathrm{~m}$ that year. The $\mathrm{O}_{2}$ concentrations in the Rhône were as high as $11 \mathrm{mg} \mathrm{L}^{-1}$, and we assumed that the Dranse waters were also saturated. It is then unlikely that the observed oxygen depletion in the turbidity current observed in the upper hypolimnion directly resulted from intrusions of $\mathrm{O}_{2}$-depleted river waters. Instead, it points to increased oxygen consumption in the uppermost turbidity current, for which the metabolic consequences of the riverborne inputs would have taken over its physical, mixing effect.

These observations suggested (i) that the respiration of diluted, river-borne organic matter in the hypolimnion had a significant effect on oxygen concentrations and (ii) that the contribution of respiration varied between the upper and lowermost hypolimnion. The oxygen consumption experiment that we designed, a posteriori, aimed to test whether such assumptions were reasonable. Although $\mathrm{O}_{2}$ and DOC concentrations in the hypolimnetic waters were likely to be relatively similar in October to those right before the flood, they were undoubtedly quite different for the river waters. However, this experiment did not intend to mimic conditions during the flood but instead to investigate the metabolic processes in the different hypolimnetic layers.

\subsection{Hypolimnetic respiration of river-borne organic matter}

Bioassays intended to test the possibility of fast and efficient respiration of river-borne organic matter in the lake hypolimnion as suggested by the field data, such as for depthrelated differences in the metabolic processing of this organic matter. Ideally, the experiment should have been conducted during the studied flooding event, but the available background literature at the time of study argued for a refractory nature of allochthonous organic matter, hampering fast and significant metabolic processing within the lake. The flood we had studied was of exceptional amplitude (a 50-year return time at least for the Dranse River) and was not likely to occur again any time soon. The point of the bioassays was then to investigate the processes underlying the observed field results, and we were lucky enough that even for different flowing conditions, bioassay results reflected the field conditions very well. This stresses the fact these processes may not be exceptional; instead, their overall contribution to the lake $\mathrm{O}_{2}$ budget becomes more significant in flowing conditions.

Microbial respiration rates for the Dranse water were initially 3 times those of the lake hypolimnetic waters, for similar DOC concentrations. In order to best reproduce processes occurring during the river intrusion into the lake, we did not filter water to remove plankton before incubations, in contrast to experiments aiming at separating bacterial and planktonic respiration rates (Warkentin et al., 2007). It is therefore likely that the respiration was higher in the Dranse water samples because it included both bacterial and autotrophic planktonic components compared to samples from the dark hypolimnetic layers in which only microbial heterotrophs are present.

However, considering a respiratory quotient of 0.82 (Williams and del Giorgio, 2005), consumed $\mathrm{O}_{2}$ in the Dranse River samples after $86 \mathrm{~h}$ would correspond to the oxidation of $0.75 \mathrm{mgC} \mathrm{L}^{-1}$, i.e. $>90 \%$ of TOC. These values of short-term oxygen consumption rates belong to the upper end of the range reported for lakes and streams by Berggren et al. (2012). They attest to an important shortterm labile pool of DOC (sensu Guillemette and del Giorgio, 2011) in the river waters (low molecular weight, relatively young DOC; Agren et al., 2008) but also to low bacterial growth efficiency due to nutrient limitation in the oligotrophic conditions of the Dranse River (Cimbleris and Kalff, 1998; Wiegner and Seitzinger, 2004). River water samples were collected for the experiment purposes at times of moderate hydrological loads, and DOC as well as phosphate concentrations in the river during the flood were much higher, suggesting fast leaching of the watershed soils (Agren et al., 2008). It is likely that river DOC during the flood was even more labile, since it was mobilized and transported by rapid flush and fast transport of soil organic matter (Agren et al., 2008; Bergström and Jansson, 2000).

In contrast, respiration recorded in the lake hypolimnetic waters corresponded to lower oxidation rates ( 23 and $42 \%$ of TOC at 100 and $200 \mathrm{~m}$ depths, respectively) for similar initial organic carbon contents. Bacterial growth (including respiration, production, and growth efficiencies) depends both on nutrient limitation and organic-matter quality (Farjalla et al., 2009). At these depths, microbial metabolism is less likely to be nutrient limited but bacterial abundances are neverthe- 
less usually low (around $10^{5}$ cells $\mathrm{mL}^{-1} ; \mathrm{S}$. Jacquet, personal communication, 2015) suggesting low values for bacterial production. Moreover, hypolimnetic waters of Lake Geneva have long residence times (time of $\sim 20$ years; Meybeck, 1970) and although most of the lakes' hypolimnetic DOC may primarily originate from autochthonous primary production, DOC aging through microbial reworking contributes to increasing its aromaticity (Berggren et al., 2009), resulting in low bacterial growth efficiencies even without nutrient limitation (Berggren et al., 2009). In this case, lower respiration values for hypolimnetic waters suggested that lake DOC was semi-labile as compared to the Dranse DOC that may be fresher and more readily available.

Nevertheless, higher oxygen consumption rates measured for the lowermost hypolimnion as compared to its upper layer are surprising at first sight as they point to a higher availability of lake DOC of greater depths. Such depth-related differences in $\mathrm{C}$ availability for the microbial metabolism are also consistent with the substitution assays showing that river-borne, labile DOC inputs stimulated microbial respiration only for the supposedly $\mathrm{C}$-limited samples, i.e. the $100 \mathrm{~m}$ depth lake water (Eiler et al., 2003). If DOC had the same sources in both hypolimnetic layers, the greater water retention time would instead contribute to decreasing DOC bioavailability with depth. Yet, DOC concentrations increase between the lower limit of the mixed hypolimnion $(110 \mathrm{~m})$ and the lake bottom $(309 \mathrm{~m})$, from 0.7 to $0.8 \mathrm{mg} \mathrm{CL}^{-1}$, as a likely consequence of DOC remobilization from the sediment and accumulation in the overlying water column (Gonsior et al., 2013). Recent studies highlighted that DOC release from the sediment is a substantial source of labile DOC to the water column (Downing et al., 2008), which could increase the short-term labile pool of DOC in the unmixed hypolimnion. While additional investigation of deep-DOC quality would be required, fluxes of sediment DOC to the unmixed deeper hypolimnetic layer could sustain higher respiration rates as compared to the most superficial layer, for which the microbial metabolism is most limited by organicmatter quality.

More surprisingly though, the stimulation of microbial respiration for the $100 \mathrm{~m}$ depth treatment was disproportionate compared to the quantity of added labile organic carbon (OC). The substitution of $1-10 \%$ of lake DOC by riverborne, more labile DOC led to respiration exceeding values that would be expected from simple mixing models of singlesource yields by $60 \%$. Similar over-yield respiration effects were documented by Farjalla et al. (2009), who observed that a mixture of fresh and aged DOC acted synergistically on the bacterial respiration rate (Farjalla et al., 2009), resulting in disproportionately increased rates compared to single substrates. We did not filter the Dranse water to remove microbes prior to incubations, with the purpose of more closely replicating realistic conditions within turbidity currents, and it is likely that we added an inoculum of river microbes to the mixture experiments. Increased respiration of particulate carbon would have been an explanation if the riverine water has been rich in particulate organic carbon (POC). However, for both lake and river waters, $\mathrm{POC}$ concentrations were basically beyond detection limits $\left(<0.1 \mathrm{mg} \mathrm{L}^{-1}\right)$ and, as for DOC, do not account for the excess oxygen consumption. A greater microbial diversity in the mixture samples could also favour co-metabolism on carbon compound decomposition and therefore the observed over-yielding, as suggested by Farjalla et al. (2009). Yet, more recent investigations revealed that the initial microbial community composition has less impact on DOC use than the nature of DOC itself (Attermeyer et al., 2014). The microbial riverine inoculum may then not account for the totality of the enhanced decomposition of DOC in the mixture, while metabolic synergies in the microbial use of the different DOC qualities could also be involved (Fonte et al., 2013).

\subsection{Experimental and observational conclusions on the effect of river intrusion on the hypolimnetic oxygen concentrations of Lake Geneva}

The May 2015 flood episodes did not trigger true underflow processes. Therefore, we cannot generally exclude that underflows, in which very high turbidity limits the mixing of the water masses of the river and the lake, can finally replenish deep-water oxygen. However, rough estimations confirmed that such true underflow processes are far more rare than previously thought. Exceptional events that indeed replenish oxygen at the bottom of the lake may occur on decennial, rather than annual timescales. Our observations pointed to no or a negative effect of river intrusions on the deep-water oxygen content of Lake Geneva. Rather than increasing deepwater oxygen concentrations, these intrusions cause physical mixing of the deep hypolimnion, i.e. redistributing oxygen over depth, or have a metabolic effect at least on the temporal scale at which we observed the process (i.e. 3 days after the discharge peak). It is likely though that these patterns may have followed a temporary and even shorter-lasting increase in oxygen in the intrusion within the first hours of the event. The final consequences for the benthic biota are unclear since the effect on $\mathrm{O}_{2}$ may be transient and will not persist for long within the lake hypolimnion. Indeed, the change in the deep hypolimnion $\mathrm{O}_{2}$ profiles due to the homogenization by the intrusion was poorly visible during the monitoring survey performed at SHL2 a few days after the end of the flooding event (11 May, data not shown). The mechanisms by which river water intrudes both above and below the deep-mixing layer remain to be investigated, such as the associated differences in the metabolic fate of river-borne organic matter. Nevertheless, our observational survey and bioassays highlighted that these intrusions provide interfaces where riverine and lake organic matter are mixed and can act as biogeochemical hot spots. The quantity of substituted DOC does not account for the excess oxygen consumption observed in the L100-99\% and L100-90 \% treatments. Fertilization and 
nitrification effects, such as respiration of particulate organic matter, could be reasonably ruled out in both the field survey and bioassays. Instead, our results suggest that more of the lake DOC, from intermediate hypolimnetic depth, had been respired as a small fraction of more labile, river-borne, dissolved organic-matter (DOM) was substituted. Even if the role played by a potential inoculum of riverine microbes cannot be ruled out, river intrusions into the upper hypolimnion resulted in an increase in autochthonous organic-matter respiration. This mechanism, by which a small addition of labile organic matter, stimulates the mineralization of less available organic matter is referred to as the "priming effect". The priming effect has been thoroughly investigated in soils, but evidence is still sought in aquatic systems (Bianchi, 2011; Catalán et al., 2015). River plumes have been identified as sites prone to host the priming effect, since they bring different sources of organic matter of varying quality into contact (Bianchi, 2011; Guenet et al., 2010). Even though several papers, along with the present results, have revised the long-standing hypothesis of the recalcitrance of terrestrial organic matter (Guillemette and del Giorgio, 2011; Roehm et al., 2009), investigations of the aquatic priming effect are still based on the hypothesis that lacustrine organic matter (OM) is the primer and terrestrial OM the "primed" (Catalán et al., 2015). In the present study, the vertical consideration of the intrusion challenged our preconceived thoughts on the quality of aquatic DOC, showing that lacustrine DOC was semilabile but of heterogeneous quality with depths, while river $\mathrm{OM}$ was potentially acting as the primer. Even though a formal demonstration of the priming effect requires further evidence, our in situ and ex situ observations suggest that deepriver intrusion into Lake Geneva could be potential hot spots for aquatic priming, fostering the mineralization of deep, less labile lacustrine organic matter.

\section{The Supplement related to this article is available online at doi:10.5194/bg-13-3573-2016-supplement.}

Author contributions. Both authors contributed equally to the field work, the data analysis, and the redaction of the manuscript.

Acknowledgements. The three anonymous reviewers provided helpful comments on a previous version of this manuscript. The authors thank Johny Wüest, Martin Schmid, and Beat Müller for their comments on a previous draft. The authors also thank Robert Schwefel for his help in the field.

Edited by: B. A. Pellerin

\section{References}

Agren, A., Berggren, M., Laudon, H., and Jansson, M.: Terrestrial export of highly bioavailable carbon from small boreal catchments in spring floods, Freshwater Biol., 53, 964-972, 2008.

Alavian, V., Jirka, G. H., Denton, R. A., Johnson, M. C., and Stefan, H. G.: Density currents entering lakes and reservoirs, J. Hydraul. Eng., 118, 1464-1489, 1992.

Alvarez-Cobelas, M., Angeler, D. G., Sánchez-Carrillo, S., and Almendros, G.: A worldwide view of organic carbon export from catchments, Biogeochemistry, 107, 275-293, doi:10.1007/s10533-010-9553-z, 2010.

Attermeyer, K., Hornick, T., Kayler, Z. E., Bahr, A., Zwirnmann, E., Grossart, H.-P., and Premke, K.: Enhanced bacterial decomposition with increasing addition of autochthonous to allochthonous carbon without any effect on bacterial community composition, Biogeosciences, 11, 1479-1489, doi:10.5194/bg-11-1479-2014, 2014.

Berggren, M., Laudon, H., and Jansson, M.: Aging of allochthonous organic carbon regulates bacterial production in unproductive boreal lakes, Limnol. Oceanogr., 54, 1333-1342, doi:10.4319/lo.2009.54.4.1333, 2009.

Berggren, M., Lapierre, J.-F., and del Giorgio, P. A.: Magnitude and regulation of bacterioplankton respiratory quotient across freshwater environmental gradients, ISME J., 6, 984-993, 2012.

Bergström, A.-K. and Jansson, M.: Bacterioplankton production in humic Lake Örträsket in relation to input of bacterial cells and input of allochthonous organic carbon, Microb. Ecol., 39, 101115, 2000.

Bianchi, T. S.: The role of terrestrially derived organic carbon in the coastal ocean: A changing paradigm and the priming effect, P. Natl. Acad. Sci. USA, 108, 19473-19481, 2011.

Bouffard, D. and Perga, M.-E. : Interactive comment on "Are flooddriven turbidity currents hot-spots for priming effect in lakes?", Biogeosciences Discuss., doi:10.5194/bg-2015-645-AC4, 2016.

Catalán, N., Kellerman, A. M., Peter, H., Carmona, F., and Tranvik, L. J.: Absence of a priming effect on dissolved organic carbon degradation in lake water, Limnol. Oceanogr., 60, 159-168, 2015.

Chen, C.-T. A. and Millero, F. J.: thermodynamic properties for natural waters covering only the limnological range1, Limnol. Oceanogr., 31, 657-662, 1986.

Cimbleris, A. C. and Kalff, J.: Planktonic bacterial respiration as a function of $\mathrm{C}: \mathrm{N}: \mathrm{P}$ ratios across temperate lakes, Hydrobiologia, 384, 89-100, 1998.

Corella, J. P., Arantegui, A., Loizeau, J.-L., DelSontro, T., Le Dantec, N., Stark, N., Anselmetti, F. S., and Girardclos, S.: Sediment dynamics in the subaquatic channel of the Rhone delta (Lake Geneva, France/Switzerland), Aquat. Sci., 76, 73-87, 2014.

Cortés, A., Fleenor, W. E., Wells, M. G., de Vicente, I., and Rueda, F. J.: Pathways of river water to the surface layers of stratified reservoirs, Limnol. Oceanogr., 59, 233-250, doi:10.4319/lo.2014.59.1.0233, 2014.

De Cesare, G., Boillat, J.-L., and Schleiss, A. J.: Circulation in stratified lakes due to flood-induced turbidity currents, J. Environ. Eng., 132, 1508-1517, 2006.

Dhillon, G. S. and Inamdar, S.: Extreme storms and changes in particulate and dissolved organic carbon in runoff: Entering uncharted waters?, Geophys. Res. Lett., 40, 1322-1327, doi:10.1002/grl.50306, 2013. 
Downing, B. D., Bergamaschi, B. A., Evans, D. G., and Boss, E.: Assessing contribution of DOC from sediments to a drinkingwater reservoir using optical profiling, Lake Reserv. Manag., 24, 381-391, 2008.

Eiler, A., Langenheder, S., Bertilsson, S., and Tranvik, L. J.: Heterotrophic bacterial growth efficiency and community structure at different natural organic carbon concentrations, Appl. Environ. Microbiol., 69, 3701-3709, 2003.

Fahrni, H. P. and Rapin, F.: Modélisation du cycle du phosphore dans le Léman, Rapports sur les études et recherches entreprises dans le bassin lémanique, Campagne, 1985, 1986.

Farjalla, V. F., Marinho, C. C., Faria, B. M., Amado, A. M., Esteves, F. de A., Bozelli, R. L., and Giroldo, D.: Synergy of fresh and accumulated organic matter to bacterial growth, Microb. Ecol., 57, 657-666, 2009.

Finger, D., Schmid, M., and Wüest, A.: Effects of upstream hydropower operation on riverine particle transport and turbidity in downstream lakes, Water Resour. Res., 42, W08429, doi:10.1029/2005WR004751, 2006.

Fischer, H. B.: Mixing in Inland and Coastal Waters, Academic Press, 1979.

Fonte, E. S., Amado, A. M., Meirelles-Pereira, F., Esteves, F. A., Rosado, A. S., and Farjalla, V. F.: The combination of different carbon sources enhances bacterial growth efficiency in aquatic ecosystems, Microb. Ecol., 66, 871-878, 2013.

Forel, F. A.: Le Léman: monographie limnologique, F. Rouge, 1892.

Gonsior, M., Schmitt-Kopplin, P., and Bastviken, D.: Depthdependent molecular composition and photo-reactivity of dissolved organic matter in a boreal lake under winter and summer conditions, Biogeosciences, 10, 6945-6956, doi:10.5194/bg-106945-2013, 2013.

Guenet, B., Danger, M., Abbadie, L., and Lacroix, G.: Priming effect: bridging the gap between terrestrial and aquatic ecology, Ecology, 91, 2850-2861, 2010.

Guillemette, F. and del Giorgio, P. A.: Reconstructing the various facets of dissolved organic carbon bioavailability in freshwater ecosystems, Limnol. Oceanogr., 56, 734-748, 2011.

Halder, J., Decrouy, L., and Vennemann, T. W.: Mixing of Rhône River water in Lake Geneva (Switzerland-France) inferred from stable hydrogen and oxygen isotope profiles, J. Hydrol., 477, 152-164, doi:10.1016/j.jhydrol.2012.11.026, 2013.

Hogg, C. A. R., Marti, C. L., Huppert, H. E., and Imberger, J.: Mixing of an interflow into the ambient water of Lake Iseo, Limnol. Oceanogr., 58, 579-592, doi:10.4319/lo.2013.58.2.0579, 2013.

Jenny, J.-P., Arnaud, F., Alric, B., Dorioz, J.-M., Sabatier, P., Meybeck, M., and Perga, M.-E.: Inherited hypoxia: A new challenge for reoligotrophicated lakes under global warming, Global Biogeochem. Cy., 28, GB004932, doi:10.1002/2014GB004932, 2014.

Johengen, T. H., Biddanda, B. A., and Cotner, J. B.: Stimulation of Lake Michigan plankton metabolism by sediment resuspension and river runoff, J. Gt. Lakes Res., 34, 213-227, 2008.

Klug, J. L., Richardson, D. C., Ewing, H. A., Hargreaves, B. R., Samal, N. R., Vachon, D., Pierson, D. C., Lindsey, A. M., O'Donnell, D. M., Effler, S. W., and Weathers, K. C.: Ecosystem effects of a tropical cyclone on a network of lakes in northeastern North America, Environ. Sci. Technol., 46, 11693-11701, 2012.

Lambert, A. and Giovanoli, F.: Records of riverborne turbidity currents and indications of slope failures in the Rhone delta of Lake Geneva, Limnol. Oceanogr., 33, 458-468, doi:10.4319/lo.1988.33.3.0458, 1988.

Lambert, A. M., Kelts, K. R., and Marshall, N. F.: Measurements of density underflows from Walensee, Switzerland, Sedimentology, 23, 87-105, 1976.

Loizeau, J.-L. and Dominik, J.: Evolution of the Upper Rhone River discharge and suspended sediment load during the last 80 years and some implications for Lake Geneva, Aquat. Sci., 62, 54-67, doi:10.1007/s000270050075, 2000.

Meiburg, E. and Kneller, B.: Turbidity currents and their deposits, Annu. Rev. Fluid Mech., 42, 135-156, 2010.

Meybeck, M.: Bilan hydrochimique et geochimique du Lac Leman, PhD Thesis, 1970.

Meybeck, M., Blanc, P., Moulherac, A. E., and Corvi, C.: Chemical evidence of water movements in the deepest part of Lake Leman (Lake Geneva), Aquat. Sci., 53, 273-289, 1991.

Moran, M. A. and Hodson, R. E.: Bacterial production on humic and nonhumic components of dissolved organic carbon, Limnol. Oceanogr., 35, 1744-1756, 1990.

Mulder, T., Syvitski, J. P., Migeon, S., Faugeres, J.-C., and Savoye, B.: Marine hyperpycnal flows: initiation, behavior and related deposits, A review, Mar. Petrol. Geol., 20, 861-882, 2003.

Ojala, A., Bellido, J. L., Tulonen, T., Kankaala, P., and Huotari, J.: Carbon gas fluxes from a brown-water and a clear-water lake in the boreal zone during a summer with extreme rain events, Limnol. Oceanogr., 56, 61-76, 2011.

Raymond, P. A. and Saiers, J. E.: Event controlled DOC export from forested watersheds, Biogeochemistry, 100, 197-209, doi:10.1007/s10533-010-9416-7, 2010.

Roehm, C. L., Giesler, R., and Karlsson, J.: Bioavailability of terrestrial organic carbon to lake bacteria: The case of a degrading subarctic permafrost mire complex, J. Geophys. Res.-Biogeo., 114, G03006, doi:10.1029/2008JG000863, 2009.

Sadro, S., Melack, J. M., and MacIntyre, S.: Depth-integrated estimates of ecosystem metabolism in a high-elevation lake (Emerald Lake, Sierra Nevada, California), Limnol. Oceanogr., 56, 1764-1780, 2011.

Tsai, J.-W., Kratz, T. K., Hanson, P. C., Wu, J.-T., Chang, W. Y., Arzberger, P. W., Lin, B.-S., Lin, F.-P., Chou, H.-M., and Chiu, C.-Y.: Seasonal dynamics, typhoons and the regulation of lake metabolism in a subtropical humic lake, Freshwater Biol., 53, 1929-1941, 2008.

Turner, J. S.: Turbulent entrainment: the development of the entrainment assumption, and its application to geophysical flows, J. Fluid Mech., 173, 431-471, 1986.

Vachon, D. and del Giorgio, P. A.: Whole-Lake $\mathrm{CO}_{2}$ Dynamics in Response to Storm Events in Two Morphologically Different Lakes, Ecosystems, 17, 1338-1353, doi:10.1007/s10021014-9799-8, 2014.

Warkentin, M., Freese, H. M., Karsten, U., and Schumann, R.: New and fast method to quantify respiration rates of bacterial and plankton communities in freshwater ecosystems by using optical oxygen sensor spots, Appl. Environ. Microbiol., 73, 6722-6729, 2007.

Wiegner, T. N. and Seitzinger, S. P.: Seasonal bioavailability of dissolved organic carbon and nitrogen from pristine and polluted freshwater wetlands, Limnol. Oceanogr., 49, 1703-1712, 2004. 
Williams, P. J. and del Giorgio, P. A.: Respiration in aquatic ecosystems: history and background, Respir. Aquat. Ecosyst. Oxf. Univ. Press Oxf., 1-17, 2005.
Wüest, A., Imboden, D. M., and Schurter, M.: Origin and size of hypolimnic mixing in Urnersee, the southern basin of Vierwaldstättersee (Lake Lucerne), Schweiz. Z. Hydrol., 50, 40-70, 1988. 